\title{
Czech Foreign Wine Trade - Comparative Advantages Distribution in Relation to the European Union
}

\author{
Jan Borák, Tomáš Vacek
}

Department of Economics, Faculty of Economics and Management, Czech University of Life Sciences Prague, Czech Republic

\begin{abstract}
The Czech agrarian foreign trade recorded significant changes since the Czech Republic joined the EU in 2004. This fact influenced also domestic and foreign wine trade of the Czech Republic. This article identifies the main changes in the product structure, and it specifies the level of Czech wine export comparative advantages' distribution in relation to European Union member states. The analysis takes into account not only the trade value (in USD) but also the trade volume (in tonnes) of particular commodities. Commodity structure (HS system is applied at a six-digit level for the more detailed analyses of trade) is analysed especially in relation to the unit price value and in relation to the comparative advantages' or disadvantages' distribution. The main analysis of the comparative advantages' distribution is based on Balassa index, Lafay index and the trade balance index. The results obtained from the individual analysis are presented by the modified "product mapping method". The territorial structure of the Czech agrarian trade is heavily focused on the trade with the European Union member states. The Czech Republic has comparative advantages in wine trade with the European Union in the following sub-aggregations: Wine of fresh grapes to 2 litres (HS 220421) and Grape must (HS 220430). Main destinations for Czech wine export are following: Slovakia, Poland and Germany.
\end{abstract}

\section{Keywords}

Comparative advantages, Czech Republic, EU, export/import, international trade, wine.

Borák, J. and Vacek, T. (2018) "Czech Foreign Wine Trade - Comparative Advantages Distribution in Relation to the European Union", AGRIS on-line Papers in Economics and Informatics, Vol. 10, No. 3, pp. 31-43. ISSN 1804-1930. DOI 10.7160/aol.2018.100303.

\section{Introduction}

Wine is produced in about sixty countries, but in most of them the produced quantity is small, even negligible. In their marketing, the traditional wine-producing countries highlight the advantages of long-term tradition of grapevine growing in particular regions (Rocchi and Stefani, 2002). Twelve most important producers produce approximately 230 million hectolitres wine, which represents $80-90 \%$ of global volume. Wine-growing regions of high quality were rather connected with their location at principal trade routes than with the natural character of soil and climatic conditions. The quality of wine also used to be associated with the social state of the vineyard's owner (Dion, 1952). The supply must focus on the quality of infrastructure, abilities and inputs of the "host" - producing country (Kuemmerle, 1999; Woodward and Rolfe, 1993). For these reasons, the vintners worldwide use different policies whose task is to prod into a better performance of international trade in wine-sector, especially in the field of entering into international relations. The goal is to share successful procedures (Fleury and Fleury, 2003; Ring and Van de Ven, 1994). Even though, according to Jeníček (2002), the development in information and transport technologies has reduced transport costs for goods, it is in terms of its economy better for the Czech Republic to aim at the European wine market. This is caused by still high transaction costs the exporters would have to incur to be able to penetrate one of the mentioned non-European markets, which Dal Bianco et al. (2014) understands as an obstacle in international trade in wine-sector. Even Dal Bianco adds that there is a descending tendency in customs and quota limitations, this is mostly compensated by stricter technical obstacles. It is also possible to focus on Euro-Asian countries, which are quite heterogeneous, when taking into consideration agricultural variables, and which 
have not undergone economic transition, which, according to Benešová et al. (2016), offers a great potential for possible future cooperation.

The share of Europe as a whole in the global production is decreasing. In 2016, the world trade in wine-sector, which is understood as the total export of all countries, reached the volume of 104.1 million hectolitres, which is almost two-fold increase during the last 20 years (1996 - volume of 54.5 million hectolitres), and the value of 32.44 billion USD, which is almost three-fold increase during the last 20 years (1996 - value 11.6 billion USD). Looking at the territorial structure of the Czech trade in wine-sector, high dependence on the trade with European Union member states is obvious. In 1996, Czech vintners' trade with the European Union reached the rate of $93 \%$, in 2016 the volume of trade reached $86 \%$. In the course of the monitored period from 1996 to 2016, the share of European Union countries never decreased below $83 \%$.

In 2004, the accession of the Czech Republic to the European Union brought a lot of changes on the market in general. According to Lombardi et al. (2016), although the globalization significantly influences even this branch, the EU was influenced less negatively than other markets. Over the last few years, the consumption of wine at various population segments, that are interested in nature, motivation and own choice of wine, has been growing (Ritchie, 2007). Among alcoholic beverages, wine is one of the most popular kinds with consumers in the Czech Republic. The average annual consumption of wine grew from 15.8 litres in 1996 to 16.8 litres per capita in 2005 (Pyšný et al., 2007), and to nearly 19.8 litres per capita in 2012 (Syrovátka et al. 2014), which is more or less identical with 2016. The reason is that the quality of wine has significantly increased over the last years, mainly due to new production technologies. According to Peterová (2013), it can be in principle said that viniculture is one of the few commodities where the origin is paid. Although in the Czech Republic qualifications of wine pursuant to the German system, i.e. quality or sugar content in grapes, are more better known at the moment, according to Tomšík and Prokeš (2011) is advantageous to continue in establishing wine-grower's associations, so-called VOC, i.e. qualification of wine as to its origin (Romance system).

The negative balance of Czech foreign trade in wine-sector exceeded 173 million USD for the first time in 2011. Wine for 201.36 million
USD was imported to the Czech Republic, and the export amounted to 28.23 million USD. In the last years, import and export have been slightly rising, in any case significantly higher amount of wine is imported to the Czech Republic from abroad than that which is exported. In 2016, the genitive balance amounted to 158 million USD. Because the negative balance of the foreign trade in wine-sector has already exceeded 163 million USD, there is a certain space here for increasing the domestic production, as the inquiry from the Czech consumers is here. As Tomšík and Sedlo (2013) add, the Czech Republic is among countries dependent on the import of wine, whereby one third of the consumed volume of wine comes from the domestic production, and two thirds are imported. For this reason, it is necessary to pay careful attention to the trade in wine-sector and to focus on Czech Republic's comparative advantages in relation to the global market (especially EU market) in wine trade. According to Tomšík and Sedlo (2013), from the perspective of winegrowers, it would be even very suitable to organize and check imports based on the domestic production, as the volume of imported wine is influenced by the domestic production, while the volume of export is not, and it is gradually increasing.

\section{Materials and methods}

This article aims to identify changes on the market with wine, which occurred in the course of the analysed period from the year 1996 to the year 2016. The monitored period includes several years before and after the Czech Republic joined the EU (in 2004). In addition to individual changes, other particular factors are specified, which are responsible for these changes. The territorial structure is analysed in relation to EU countries. The structure of commodity (we use the HS system which divides the trade in winesector into four basic aggregations) is analysed especially in relation to the development and distribution of added value. The mentioned system is applied because of the simple interpretation of results and because of data availability.

The commodity structure on wine market is given by a 6-digit numeric code that divides the wine market into 4 commodity groups:

\section{HS 220410 Sparkling wine of fresh grapes}

HS 220421 Wine of fresh grapes, incl. fortified wines, and grape must whose fermentation has been 
arrested by the addition of alcohol, in containers of $<=21$ (excl. sparkling wine)

HS 220429 Wine of fresh grapes, incl. fortified wines, and grape must whose fermentation has been arrested by the addition of alcohol, in containers of $>21$ (excl. sparkling wine)

\section{HS 220430 Other grape must}

The article also specifies the distribution of comparative advantages in relation to the EU single market. To reach the above- mentioned aim, the essay applies basis analysis of the distribution of comparative advantages (Balassa Index, Lafay Index and the index of trade balance). Results from particular analyses are interpreted using "product maps", which identify the process of formation of the Czech foreign wine trade and its commodity structures. Figures for particular analyses were drawn upon UN COMTRADE. Cash-flows are mentioned in USD and volumes are mentioned in tonnes.

For the analysis of comparative advantages within the global market or within partial markets the RCA Index will be used as a tool, which also was used in the case of Smutka and Burianová (2013). This index expresses the relative rate of comparative advantage at particular groups of goods, and its value is interpreted as an export ratio of a certain group of goods to the total export in relation to a certain group of countries. The degree of export strategy can be define according to the following formula (1):

$\mathrm{RCA}=\left(X_{i j} / X_{i t}\right) /\left(X_{n j} / X_{n t}\right)=\left(X_{i j} / X_{n j}\right) /\left(X_{i t} / X_{n t}\right)$

where $X_{i j}$ stands for the export of the corresponding group of goods from a given country, $X_{i t}$ stands for the total export of goods from a given country, $\mathrm{X}_{n j}$ symbolises the export of a certain group of goods in relation to a certain group of countries, and $X_{n t}$ corresponds to the total export of goods from a certain group of countries.

If the value of Balassa Index is higher than 1, the comparative advantage is proven. If, in contrast, this index shows values less than 1 , it can be said that a comparative advantage was not proven in the case of a given country. Furthermore, it must be noted that Balassa Index has not upper limit, but the bottom limit is equal to 0 (Balassa, 1965).

The comparative advantages shall be analysed at a bilateral level, as Smutka et al. (2014) analysed in his article about current global state of sugar. For the analysis of comparative advantages within the global market, the LFI index will be used as a tool, which also was used by Smutka et al. (2016). This index provides information about the existence of comparative advantages at a bilateral level, i.e. only within two entities, doing trade between each other, where $x_{i j}$ and $m_{i j}$ stand for export and import of the product " $j$ " from a country or a group of countries " $i$ " in relation to the rest of the world (2).

If the LFI value is positive, the comparative advantage exists; the higher the values of this index is, the higher is the degree of specialization in the given country. In contrary, a negative value of the LFI index means missing specialization, i.e. comparative advantages. Lafay Index allows the position of each particular product to be analysed within the structure of international trade at each particular analysed country or a group of countries (Zaghiny, 2003).

$$
L F I_{j}^{i}=\left(\frac{x_{j}^{i}-m_{j}^{i}}{x_{j}^{i}+m_{j}^{i}}-\frac{\sum_{j=1}^{N}\left(x_{j}^{i}-m_{j}^{i}\right)}{\sum_{j=1}^{N}\left(x_{j}^{i}+m_{j}^{i}\right)}\right) \frac{x_{j}^{i}+m_{j}^{i}}{\sum_{j=1}^{N}\left(x_{j}^{i}+m_{j}^{i}\right)} * 100
$$

Index of the foreign-trade balance (TBI) is used for the analysis of whether the county is specialized in export (as a pure exporter), or import (as a netto importer) for a certain group of products. TBI is formulated, as follows (3):

$$
T B I_{i j}=\left(x_{i j}-m_{i j}\right) /\left(x_{i j}+m_{i j}\right)
$$

where $T B I_{i j}$ indicates the index of country's balance of trade even for the product " $j$ "; $x_{i j}$ and $m_{i j}$ represent export and import of a group of products according to country " $i$ " (Lafay, 1992). This index was also used by Smutka et al. (2018).

The country is in a particular group of products indicated as a "pure importer", if the TBI value is negative, and as a "pure exporter", if the TBI value is positive. (Widodo, 2009)

The further part of analysis submitted in this document was implemented by means of an analytic tool called "product maps". This tool allows the user to evaluate premier exported production from two different perspectives, i.e. domestic balance of trade and international competitiveness (Widodo, 2009).

This tool is a matrix for the division of a set 


\begin{tabular}{|c|c|c|c|}
\hline \multirow{2}{*}{ 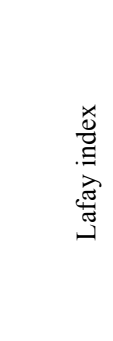 } & 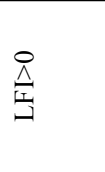 & $\begin{array}{l}\text { Group B: } \\
\text { Comparative Advantage } \\
\text { Net-importer } \\
(\mathrm{LFI}>0 \text { and } \mathrm{TBI}<0)\end{array}$ & $\begin{array}{l}\text { Group A: } \\
\text { Comparative Advantage } \\
\text { Net-exporter } \\
(\mathrm{LFI}>0 \text { and } \mathrm{TBI}>0)\end{array}$ \\
\hline & $\frac{\stackrel{P}{V}}{\stackrel{I}{U}}$ & $\begin{array}{l}\text { Group D: } \\
\text { Comparative disadvantage } \\
\text { Net-importer } \\
(\mathrm{LFI}<0 \text { and } \mathrm{TBI}<0)\end{array}$ & $\begin{array}{l}\text { Group C: } \\
\text { Comparative disadvantage } \\
\text { Net-exporter } \\
(\mathrm{LFI}<0 \text { and } \mathrm{TBI}>0)\end{array}$ \\
\hline \multicolumn{2}{|c|}{$\begin{array}{c}\text { Czech Agrarian Foreign Trade } \\
\text { Commodity Structure }\end{array}$} & $\mathrm{TBI}<0$ & $\mathrm{TBI}>0$ \\
\hline
\end{tabular}

Source: Smutka et al. (2017)

Figure 1: Product maps LFI vs TBI.

of exported products into 4 groups according to two chosen coefficients using the original RSCA index, which was replaced by the LFI index that is supplemented by the TBI index, see Figure 1 (Smutka et al., 2017).

The original approach does not take into account the real intensity; in takes into consideration only the influence of import, and the original "product map" is slightly corrected. The LFI index is used here to receive more detailed figures about the real rate of comparative advantage.

\section{Results and discussion}

When looking at the summary of chosen aggregations (Table 1) it is clear that the Czech Republic recognized a long-term negative balance of trade in aggregations relating to wine. This is largely, according to Kraus et al. (2005), caused by unfavourable conditions of Czech vintners, such as limited area of vineyards as compared to important Western producers, or climatic conditions in temperate zone. On the other hand, the dynamic growth of export value must be assessed positively, as it increased 21-times (as compared to the import, which increased only 6.6-times). This development led to the increase in the coverage of import by export up to more than $13 \%$. However, this is a tendency that has decreased recently for the reason of the reduction in total production in favour of the production with higher added value. This allows Czech producers to expand to demanding wine markets, and to focus on premium brands with higher quality.

Looking at the territorial structure of the Czech trade in wine-sector, high dependence on the trade with European Union member states is obvious (EU28). In 1996, Czech vintners' trade with European Union reached the rate of $93 \%$, in 2016 the volume of trade reached $86 \%$. In the course of the monitored period from 1996 to 2016, the share of European Union countries never decreased below 83\%. Neighbouring countries - Slovakia, Poland and Germany - are the most important trade partners in terms of export value. To Slovakia, $57 \%$ of the total Czech wine export was transported in 2016. The states with the most important share in import to the Czech Republic include Italy, Spain, Slovakia and Hungary. In 2016, Italian producers imported to the Czech Republic about $28 \%$ of the total import, Spain with its share of nearly $26 \%$ was on the second place, then Hungary with $12.5 \%$, and Slovakia with nearly $7 \%$ on the fourth place.

In 2016 , the import consisted from $59 \%$ of white wine, $72 \%$ of which was imported in barrels. As to red wine, the relation between bottled wine and wine in barrels is almost balanced. We have to evaluate positively the development of the Czech Republic export unit prices which exceed the import unit prices in the course of the entire monitored period. Important was the significant deceleration in import prices between 2004 and 2016.

Export reached its historical maximum in 2013, when the total export reached 335 thousand hectolitres wine. After 2013, a sharp drop started, which was caused mainly by the change in the strategy of Czech vintners. They began to try to prefer the production of high-quality grapes of which they could produce wine of higher quality. The difficulty of this approach consists in higher demands on producers, and, of course, in lower yields per hectare. The average rate of increase in the value of Czech export was $17.53 \%$ between 1996 and 2016.

The total Czech import in the course of the monitored period was growing, and so was the export. The average growth rate reached the value of $10.45 \%$. As in the case of export, the decrease occurred after 2013. The reason for this decrease was a monetary intervention commenced 


\begin{tabular}{|r|r|r|r|r|r|r|}
\hline & \multicolumn{7}{|c|}{ EU 28 (all 4 aggregations) } \\
\hline & \multicolumn{1}{|c|}{ Export } & $\begin{array}{c}\text { Export unit } \\
\text { price / tonne }\end{array}$ & \multicolumn{1}{c|}{ Import } & $\begin{array}{c}\text { Import unit } \\
\text { price / tonne }\end{array}$ & \multicolumn{1}{c|}{ Balance } & $\begin{array}{c}\text { Coverage of import } \\
\text { by export }\end{array}$ \\
\hline 1996 & 1045522 & 1213.80 & 26000243 & 794.31 & -24954721 & $4.02 \%$ \\
\hline 2004 & 4499227 & 1699.51 & 77496184 & 1345.93 & -72996957 & $5.81 \%$ \\
\hline 2016 & 22491906 & 2128.82 & 171945595 & 1689.19 & -149453689 & $13.08 \%$ \\
\hline $\begin{array}{l}\text { Basis index } \\
2004 / 1996\end{array}$ & 4.30 & 1.40 & 2.98 & 1.69 & 2.93 & N/A \\
\hline $\begin{array}{l}\text { Basis index } \\
2016 / 2004\end{array}$ & 5.00 & 1.25 & 2.22 & 1.26 & 2.05 & N/A \\
\hline
\end{tabular}

Source: UN Comtrade, own calculations (2018)

Table 1: Overview table export/import for all 4 aggregations (USD).

in November 2013 by the Czech National Bank. At the end of the year 2013, American dollar was right below $20.00 \mathrm{CZK} / \mathrm{USD}$, but during the year 2015 it reached the level of $25.50 \mathrm{CZK} / \mathrm{USD}$. This weakening of the Czech crown led to the increase of prices of imported goods, which touched also the wine-sector.

Especially, the commodity aggregations HS 220421 and HS 220429 have an essential impact on the total balance. The total balance is significantly negative in both cases, but we have to emphasize the existence of much more dynamic growth of exports in comparison to imports. The negative balance is mainly caused by the export of large volumes from wine superpowers, such as Italy and Spain. If we concentrate on unit prices, we can find out that Czech vintners succeed in exporting their products for higher prices, than those of imported goods from the European Union to the Czech Republic. This fact is supported by the dynamically growing export unit prices, which e.g. between the years 1996 and 2016 rose approx. 1.3-times.

The following part of the paper is focused on individual analysed aggregations trade performance analysis.

Trade with sparkling wine showed a dynamic growth in the course of the total monitored period (Table 2). Especially France and Italy participated in import flows, as they exported sparkling wine with the total value of 14 million USD (in 2016) to the Czech Republic. Czech exporters established themselves with that commodity mainly on two markets. The first one can be defined as the market with neighbouring countries, i.e. with Germany, Austria, Slovakia and Poland. The other important destination for exporters includes the Benelux countries, especially Belgium and the Netherlands. Noteworthy is also the fact that between 2004 and 2016, the tendency of more quickly increasing imports as compared to exports occurred, which was negatively manifested on the degree of the coverage of import by export, i.e. decrease by $2.38 \%$.

In the case of trade with commodity aggregation HS 220421, it is necessary to mention the dynamics in export growth, which regularly exceed import in the course of the monitored period (Table 3 ). This tendency was caused, until 2013, mainly by the increasing volume of grown grapevine, and the Czech export was thus supported mainly by the volume. After 2013, the producers revised their strategy and started the production of quality wines, which also means a challenge in the form of lower yields per hectare. To a certain extent, this change manifested itself in the territorial structure. After 2000, it was Slovakia and Hungary that became the main export partners. In 2016, the positions of both states were different - while Slovakia remained the most important export market, the position of Hungary weakened. For the Czech Republic, the dynamically evolving Polish market became very important, and only then the markets in Germany and Rumania. The position of Hungary was even behind these countries in 2016. In the case of import of the aggregation "Wine in containers smaller than 2 litres", the most important positions were occupied by wine superpowers France and Italy. Around the year 2000, the position of Hungarian importers was very strong as well, however, they were losing their positions in the course of the entire monitored period, being replaced by product from Germany and Spain.

Table 4 shows us the basic overview about the development of trade with the European Union in the branch of aggregation "Wine in containers bigger than 2 litres", which we could divide into three development stages. The decreasing share of exports was running throughout the monitored period until 2006; it was caused mainly by the decrease in exports to Finland 


\begin{tabular}{|r|r|r|r|r|r|r|}
\hline & \multicolumn{7}{|c|}{ EU 28 (HS 220410) } \\
\hline & \multicolumn{1}{|c|}{ Export } & $\begin{array}{c}\text { Export unit } \\
\text { price / tonne }\end{array}$ & \multicolumn{1}{c|}{ Import } & \multicolumn{1}{c|}{$\begin{array}{c}\text { Import unit } \\
\text { price / tonne }\end{array}$} & \multicolumn{1}{c|}{ Balance } & $\begin{array}{c}\text { Coverage } \\
\text { of import by export }\end{array}$ \\
\hline 1996 & 234109 & 1974.99 & 2067220 & 1117.06 & -1833111 & $11.32 \%$ \\
\hline 2004 & 717707 & 2727.58 & 5099384 & 2911.86 & -4381677 & $14.07 \%$ \\
\hline 2016 & 2394693 & 4364.72 & 20490103 & 3582.37 & -18095410 & $11.69 \%$ \\
\hline $\begin{array}{l}\text { Basis index } \\
2004 / 1996\end{array}$ & 3.07 & 1.38 & 2.47 & 2.61 & 2.39 & N/A \\
\hline $\begin{array}{l}\text { Basis index } \\
2016 / 2004\end{array}$ & 3.34 & 1.60 & 4.02 & 1.23 & 4.13 & N/A \\
\hline
\end{tabular}

Source: UN Comtrade, own calculations (2018)

Table 2: Overview table export/import for HS 220410 (USD).

\begin{tabular}{|r|r|r|r|r|r|r|}
\hline & \multicolumn{7}{|c|}{ EU 28 (HS 220421) } \\
\hline & \multicolumn{1}{|c|}{ Export } & $\begin{array}{c}\text { Export unit } \\
\text { price / tonne }\end{array}$ & \multicolumn{1}{c|}{ Import } & $\begin{array}{c}\text { Import unit } \\
\text { price / tonne }\end{array}$ & \multicolumn{1}{c|}{ Balance } & $\begin{array}{c}\text { Coverage of import } \\
\text { by export }\end{array}$ \\
\hline 1996 & 656935 & 1102.98 & 8588670 & 830.12 & -7931735 & $7.65 \%$ \\
\hline 2004 & 3654734 & 1609.18 & 38211870 & 1164.55 & -34557136 & $9.56 \%$ \\
\hline 2016 & 18275010 & 2169.99 & 100666192 & 1818.06 & -82391182 & $18.15 \%$ \\
\hline $\begin{array}{l}\text { Basis index } \\
2004 / 1996\end{array}$ & 5.56 & 1.46 & 4.45 & 1.40 & 4.36 & N/A \\
\hline $\begin{array}{l}\text { Basis index } \\
2016 / 2004\end{array}$ & 5.00 & 1.35 & 2.63 & 1.56 & 2.38 & N/A \\
\hline
\end{tabular}

Source: UN Comtrade, own calculations (2018)

Table 3: Overview table export/import for HS 220421 (USD).

\begin{tabular}{|r|r|r|r|r|r|r|}
\hline & \multicolumn{7}{|c|}{ EU 28 (HS 220429) } \\
\hline & \multicolumn{1}{|c|}{ Export } & $\begin{array}{c}\text { Export unit } \\
\text { price / tonne }\end{array}$ & \multicolumn{1}{c|}{ Import } & $\begin{array}{c}\text { Import unit } \\
\text { price / tonne }\end{array}$ & \multicolumn{1}{c|}{ Balance } & $\begin{array}{c}\text { Coverage of import } \\
\text { by export }\end{array}$ \\
\hline 1996 & 153815 & 563.42 & 15344353 & 435.75 & -15190538 & $1.00 \%$ \\
\hline 2004 & 126786 & 761.78 & 34112256 & 486.69 & -33985470 & $0.37 \%$ \\
\hline 2016 & 1650939 & 1105.15 & 49751979 & 567.84 & -48101040 & $3.32 \%$ \\
\hline $\begin{array}{l}\text { Basis index } \\
2004 / 1996\end{array}$ & 0.82 & 1.35 & 2.22 & 1.12 & 2.24 & N/A \\
\hline $\begin{array}{l}\text { Basis index } \\
\text { 2016/2004 }\end{array}$ & 13.02 & 1.45 & 1.46 & 1.17 & 1.42 & N/A \\
\hline
\end{tabular}

Source: UN Comtrade, own calculations (2018)

Table 4: Overview table export/import for HS 220429 (USD).

and Slovakia. The follow-up stage of development lasted from the year 2007 until the year 2013; it was marked by the increase in export volumes by more than 5.4-times. Slovakia was the major destination for Czech exports. The third stage featured a rapid fall in the produced quantity which also brought a drop in the total value of export. This fact was caused by the change in vintners' priorities, and the transition to the production of quality wines, which are mostly traded in the bottled (low-volume) form. In the field of export, a decrease in total imports was recorded, which was caused by the change in consumers' preferences in favour or bottled wines of higher quality. Producers from Italy and Spain were the major importers.
Trade with "Grape must" played a minor role only in the course of the monitored period, which was rather of a regional nature in the case of Czech exports. Slovakia and Poland were the major destinations of exporters. The commodity aggregation HS 220430 was imported mainly from Hungary, Italy and Spain. Grape must is a semi-product which is processed and converted into finished wine. For this reason, this item is, as compared to other wine aggregation, so small because the producers prefer trading with the final product which has a higher added value. When comparing unit prices, the export unit prices are higher. In contrast to the previous three aggregations, the difference is only minimum. 


\section{Analysis of comparative advantages}

For a better understanding of Czech wine's position within the Czech Republic's international trade with the European Union, the paper provides an overview of Czech wine exports' comparative advantages analysis by done by Balassa Index. First, the presence of comparative advantages of wines in relation to the entire agrarian trade was researched. This analysis assessed "Grape must" to be the best aggregation, as it as the only one showed a long-term growing tendency. This fact was cause by the growing value of export to Slovakia, including the quantity and the financial volume. Another factor, which influenced the resulting coefficient, was the dynamics of increase in wine aggregation export. In the course of the monitored period, the total value of wine export increased 21.5-times, in contrast to the total agrarian export which rose just 8.2-times. Furthermore, the export of agrarian aggregations of the European Union grew more dynamically than in case of wine aggregations. This development resulted in the improvement of Balassa index's values. For Czech vintners, the dynamic increase in aggregations HS 220421 and HS 220429 is very promising. Results of "Grape must" must be treated with caution as a strong increase occurred after 2012 .

The presence of comparative advantages was not proven in the case of particular wine aggregations in relation to the entire aggregation HS 22 (beverages and liquids). This fact is caused by the minor position of wine export within the entire aggregation. In 2016, the share of wine in the total volume of exports to the European Union reached only $0.11 \%$ (only $0.07 \%$ in 2002 ). The above- mentioned aggregation was under dominating influence of foreign trade with beer and soft drinks. This result included another aspect - higher share of wine from the European Union member states (especially from important producers, such as France, Italy, Spain and Portugal) in the total export of the commodity aggregation HS 22. The average year-to-year change at particular aggregations amounted to $7.48 \%$ (HS 220410), 11.83\% (HS 220421) and 13.49\% (HS 220429).

As resulting from particular commodity aggregations in relation to the entire wine-sector segment (Table 5) the Czech foreign trade reaches comparative advantages in the long term in the case of wine, both in containers smaller than 2 litres and those bigger than 2 litres (with an exception in 2016). Until 2002, comparative advantages were proven, in relation to the European Union, in the case of aggregation HS 220410. However, it suffered an important decrease in exported quantity, which, alongside the increase in export by important European producers, led to the dynamic fall of this index. The relation between the aggregation "Wine in containers smaller than 2 litres" and the aggregation "Wine in containers bigger than 2 litres" is another interesting result. Since 2010, we can observe a decrease in the Balassa Index value in the case of wine above 2 litres, and a gradual

\begin{tabular}{|r|c|c|c|c|}
\hline \multicolumn{6}{|c|}{ EU28 Balassa (4 chosen commodities) } \\
\hline & HS-220410 & HS-220421 & HS-220429 & HS-220430 \\
\hline 1996 & 1.25504 & 0.94019 & 1.05247 & 0.04698 \\
\hline 1998 & 2.42242 & 0.47157 & 1.68784 & 0.00000 \\
\hline 2000 & 1.19378 & 0.77326 & 2.14711 & 0.00474 \\
\hline 2002 & 2.16956 & 0.77288 & 0.39017 & 0.00000 \\
\hline 2004 & 0.75946 & 1.20897 & 0.25015 & 0.00000 \\
\hline 2006 & 0.84801 & 1.17300 & 0.19588 & 0.00000 \\
\hline 2008 & 0.35064 & 0.88919 & 3.38652 & 0.00033 \\
\hline 2010 & 0.20760 & 0.83716 & 3.84587 & 0.00292 \\
\hline 2012 & 0.17397 & 1.04457 & 2.30151 & 0.02303 \\
\hline 2014 & 0.29473 & 1.12075 & 1.64472 & 0.77862 \\
\hline 2016 & 0.42700 & 1.29426 & 0.61743 & 1.90762 \\
\hline Basis index 2004/1996 & 0.61 & 1.29 & 0.24 & N/A \\
\hline Basis index 2016/2004 & 0.56 & 1.07 & 2.47 & N/A \\
\hline Average year-to-year change & $-10.22 \%$ & $3.25 \%$ & $-5.19 \%$ & N/A \\
\hline
\end{tabular}

Source: UN Comtrade, own calculations (2018)

Table 5: Comparison between CZ and EU28 for aggregations HS 220410/21/29/30. 
increase in wine with a volume below 2 litres. This tendency is caused by the change Czech producers' behaviour. They are preferring to switch from the production of large volumes of wine, with which they are not able to compete with countries, such as France, which produced 43.5 million hectolitres wine in 2016 , or France, which produced even 50.9 million hectolitres wine, to the production of smaller volumes with higher quality. Such products are able to penetrate on demanding markets of important Western producers. Furthermore, the increasing tendency at the commodity aggregation HS 220430 was noticed, which began in 2008. This tendency was caused by dynamically growing exports mainly to Slovakia, where the Czech Republic exported for 18 thousand USD in 2011 (for 147 thousand USD in 2016). Observing the rate of growth in the case of particular aggregations, the position of the aggregation "Wine in containers smaller than 2 litres" seems to become stronger, which is in accordance with the tendency to produce wines of higher quality.

Resulting values of the LFI index confirmed Czech producers' and exporters' transition to the production of wine with higher added value, see Table No. 6 , which is connected mainly with commodity aggregation HS 220421. Countries for this analysis were selected on the basis of two keys - an important European producer
(Italy, France, Spain, Portugal and Germany) or an important trading partner for the Czech Republic (Austria, Poland, Slovakia and Hungary). In the case of the Czech Republic, comparative advantages were proven by the aggregation "Wine above 2 litres" for most researched countries, except for Austria, Poland and Germany. In the case of Austria and Germany, the situation was caused by a very low volume of export as compared to the volume of import. Only 16 hectolitres of this aggregation were exported to Austria (3 395 hectolitres were imported) and 1913 hectolitres to Germany (74 723 hectolitres were imported). The comparative advantage could not be proven for Poland, which was largely caused by the fact that the Czech Republic's export to its northern neighbour was diversified into all four commodity aggregations in contrast to Poland, which imported only aggregation HS 220421 to the Czech Republic.

Tables 7 and 8 present the development of product maps in the course of the monitored period. From the perspective of the Czech Republic, it would be optimal to have all aggregations in Sector A (presence of comparative advantages and positive balance of trade). This situation, however, occurred only in the case of the aggregation Grape must and only in the years 1996 and 2000. Unfortunately, for the Czech export, this concerns only an item with minimum influence on the total balance

\begin{tabular}{|l|c|c|l|c|c|}
\hline \multicolumn{3}{|c|}{ LFI $<0$} & \multicolumn{3}{c|}{ LFI > 0 } \\
\hline Country & Aggregation & Value of LFI 2016 & Country & Aggregation & Value of LFI 2016 \\
\hline France & HS-220410 & -0.00400 & France & HS-220421 & 0.00460 \\
\hline France & HS-220429 & -0.00060 & Austria & HS-220410 & 17.06463 \\
\hline Austria & HS-220421 & -13.81659 & Spain & HS-220410 & 0.00001 \\
\hline Austria & HS-220429 & -3.24804 & Spain & HS-220421 & 0.66291 \\
\hline Spain & HS-220429 & -0.66118 & Poland & HS-220410 & 0.02074 \\
\hline Spain & HS-220430 & -0.00174 & Poland & HS-220429 & 0.01315 \\
\hline Poland & HS-220421 & -0.03456 & Poland & HS-220430 & 0.00067 \\
\hline Italy & HS-220410 & -0.05695 & Italy & HS-220421 & 0.00055 \\
\hline Italy & HS-220429 & -0.13543 & Slovakia & HS-220410 & 0.90947 \\
\hline Italy & HS-220430 & -0.00151 & Slovakia & HS-220421 & 21.34862 \\
\hline Slovakia & HS-220429 & -22.94458 & Slovakia & HS-220430 & 0.68649 \\
\hline Germany & HS-220421 & -3.18303 & Germany & HS-220410 & 1.31793 \\
\hline Germany & HS-220430 & -0.00191 & Germany & HS-220429 & 1.86701 \\
\hline Hungary & HS-220429 & -3.59718 & Hungary & HS-220410 & 0.26377 \\
\hline Hungary & HS-220430 & -0.31108 & Hungary & HS-220421 & 3.64449 \\
\hline Portugal & HS-220410 & -0.00002 & Portugal & HS-220421 & 0.00051 \\
\hline Portugal & HS-220429 & -0.00049 & & & \\
\hline
\end{tabular}

Source: UN Comtrade, own calculations (2018)

Table 6: Comparison between CZ and selected countries for aggregations HS 220410/21/29/30. 


\begin{tabular}{|l|c|c|c|c|c|c|c|c|c|}
\hline B - 1996 & Export & Share in export & Import & Share in import & A - 1996 & Export & Share in export & Import & Share in import \\
\hline HS-220410 & 234109 & $22.39 \%$ & 2067220 & $7.95 \%$ & HS-220430 & 663 & $0.06 \%$ & 0 & $0.00 \%$ \\
\hline HS-220421 & 656935 & $62.83 \%$ & 8588670 & $33.03 \%$ & & & & & \\
\hline Total & 891044 & $85.22 \%$ & 10655890 & $40.98 \%$ & Total & 663 & $0.06 \%$ & 0 & $0.00 \%$ \\
\hline D - 1996 & Export & Share in export & Import & Share in import & C - 1996 & Export & Share in export & Import & Share in import \\
\hline HS-220429 & 153815 & $14.71 \%$ & 15344353 & $59.02 \%$ & & & & & \\
\hline Total & 153815 & $14.71 \%$ & 15344353 & $59.02 \%$ & Total & & & & \\
\hline
\end{tabular}

Source: UN Comtrade, own calculations (2018)

Table 7: Relation between LFI and TBI, year 1996, in relation CZ x EU (USD).

\begin{tabular}{|l|c|c|c|c|c|c|c|c|c|}
\hline B - 2016 & Export & Share in export & Import & Share in import & A - 2016 & Export & Share in export & Import & Share in import \\
\hline HS-220421 & 18275010 & $81.25 \%$ & 100666192 & $58.55 \%$ & & & & & \\
\hline HS-220430 & 171264 & $0.76 \%$ & 1037321 & $0.60 \%$ & & & & & \\
\hline Total & 18446274 & $82.01 \%$ & 101703513 & $59.15 \%$ & Total & & & & \\
\hline D - 2016 & Export & Share in export & Import & Share in import & C - 2016 & Export & Share in export & Import & Share in import \\
\hline HS-220410 & 2394693 & $10.65 \%$ & 20490103 & $11.92 \%$ & & & & & \\
\hline HS-220429 & 1650939 & $7.34 \%$ & 49751979 & $28.93 \%$ & & & & & \\
\hline Total & 4045632 & $17.99 \%$ & 70242082 & $40.85 \%$ & Total & & & & \\
\hline
\end{tabular}

Source: UN Comtrade, own calculations (2018)

Table 8: Relation LFI and TBI, year 2016, in relation CZ x EU (USD).

of foreign trade. Otherwise, wine aggregations are present only in Sectors B and D, for which the existence of negative balance of trade is a common denominator. Czech exporters do not have many possibilities to response to this situation, as they have only limited opportunities of production due to small area of vineyards in comparison to countries, such as Spain (the most important area of vineyards in the European Union, 975 thousand hectares, only 171.7 thousand hectares in the Czech Republic).

Wine below 2 litres is the major export commodity aggregation over the entire monitored period. In 1996, its share in the entire export was $62.83 \%$ (and $81.25 \%$ in the year 2016). This aggregation is exported to Slovakia, Poland and Germany, and the export proportion to Romania has increase in the last years. From the point of view of important Western wine producers, Czech exporters succeeded to penetrate especially Spanish and Italian markets. The above-mentioned aggregation dominates even the import volumes alongside Wine above 2 litres. During the monitored years, the ratio between these items fully reversed. While in 1996, the import ratio between Wine above 2 litres and Wine below 2 litres was nearly $2: 1$, over selected years this ratio exactly reversed. This tendency occurred thanks to consumers' preferences. Czech consumers began to show higher interest in higher-quality sorts of wines, which are associated mainly with bottled wine.

Even though the Czech Republic was not able to show positive balance of trade with the European Union, it succeeded in creating comparative advantages. From the year 1996 and the year 2008, the commodity aggregation "Sparkling wine" showed a comparative advantage. From the perspective of particular countries, the Czech Republic showed a comparative advantage in relation to e.g. Germany. Over time, the influence of this item decreased due to the dynamically growing turnover in the case of items HS 220421 a HS 220429. From the general point of view, it was Sector B that showed the most important share in the monitored years and whose share in the export was approximately $85 \%$ in the year 1996, and $82 \%$ in the year 2016 .

As found out from the analysis of unit prices, the Czech Republic in its trade with the European Union exports for higher average unit prices, than those for which it imports. This situation has resulted from the comparison with EU 15 countries and EU 13 countries. Higher unit prices could be observed in the trade with traditional EU countries, which was caused by the higher standard of living of the inhabitants in these countries. The analysis of unit prices for particular countries against confirmed a stronger position of export unit prices in comparison to unit prices of imports. However, some exceptions were found, for example in the case of trade with Spain with commodity aggregation HS 220410. Very high unit prices were detected in the case of trade with the aggregation "Sparkling wine" with France and Italy, This situation 


\begin{tabular}{|l|c|c|c|c|c|c|c|c|}
\hline \multirow{2}{*}{} & \multicolumn{2}{|c|}{$\begin{array}{c}\text { unit prices HS 220410 } \\
\text { (USD/kg) }\end{array}$} & \multicolumn{2}{c|}{$\begin{array}{c}\text { unit prices HS 220421 } \\
\text { (USD/kg) }\end{array}$} & $\begin{array}{c}\text { unit prices HS 220429 } \\
\text { (USD/kg) }\end{array}$ & \multicolumn{2}{c|}{$\begin{array}{c}\text { unit prices HS 220430 } \\
\text { (USD/kg) }\end{array}$} \\
\cline { 2 - 9 } & Export & Import & Export & Import & Export & Import & Export & Import \\
\hline EU 28 & $\mathbf{4 . 3 6 4 7}$ & $\mathbf{3 . 5 8 2 4}$ & $\mathbf{2 . 1 7 0 0}$ & $\mathbf{1 . 8 1 8 1}$ & $\mathbf{1 . 1 0 5 1}$ & $\mathbf{0 . 5 6 7 8}$ & $\mathbf{0 . 8 7 5 4}$ & $\mathbf{0 . 7 8 8 5}$ \\
\hline EU 15 & $\mathbf{4 . 8 0 8 4}$ & $\mathbf{3 . 6 2 0 4}$ & $\mathbf{3 . 4 5 8 0}$ & $\mathbf{2 . 0 8 6 9}$ & $\mathbf{1 . 9 5 2 9}$ & $\mathbf{0 . 5 2 0 1}$ & N/A & $\mathbf{1 . 3 2 3 6}$ \\
\hline EU 13 & $\mathbf{3 . 8 5 6 2}$ & $\mathbf{2 . 0 7 8 7}$ & $\mathbf{2 . 1 2 5 2}$ & $\mathbf{1 . 0 0 2 0}$ & $\mathbf{1 . 0 2 5 9}$ & $\mathbf{0 . 7 0 0 6}$ & $\mathbf{0 . 8 7 5 4}$ & $\mathbf{0 . 7 1 2 1}$ \\
\hline Austria & 33.2192 & 3.0687 & 6.0654 & 3.0768 & 4.3604 & 0.8057 & N/A & N/A \\
\hline Germany & 4.9160 & 1.6136 & 3.4498 & 2.0138 & 1.9395 & 0.8642 & N/A & 2.5797 \\
\hline Poland & 3.5266 & N/A & 2.7022 & 0.3981 & 2.5789 & N/A & 3.6052 & N/A \\
\hline Slovakia & 4.0967 & 2.2438 & 1.8504 & 0.6223 & 0.8714 & 0.6935 & 0.8144 & N/A \\
\hline Hungary & 3.9058 & 2.1756 & 2.2019 & 1.2316 & 0.8532 & 0.6867 & 2.9511 & 0.7121 \\
\hline France & 13.1429 & 9.7185 & 3.6495 & 3.2410 & N/A & 1.8164 & N/A & N/A \\
\hline Italy & 11.9524 & 2.8322 & 1.3850 & 2.4561 & N/A & 0.4784 & N/A & 1.3485 \\
\hline Portugal & N/A & 4.8532 & 11.8571 & 3.5708 & N/A & 4.4134 & N/A & N/A \\
\hline Spain & 1.7477 & 1.9028 & 5.4457 & 0.9383 & N/A & 0.5229 & N/A & 1.1903 \\
\hline
\end{tabular}

Source: UN Comtrade, own calculations (2018)

Table 9: Comparison between the Czech Republic and selected groups/countries in unit prices.

confirmed an anticipation that only Czech wines of the highest quality could be able to penetrate on the demanding Western markets. Unfortunately, for Czech exporters, the export was only minimum, because only 42 litres of wine was exported to France, and only 21 litres to Italy.

\section{Conclusion}

The Czech Republic has been recorded long-term negative balance of trade in wine aggregations HS $220410 / 21 / 29 / 30$. On the other hand, the dynamic growth of export value must be assessed positively, as it increased 21-times, while import value increased only 6.6-times. Looking at the territorial structure of the Czech trade in wine-sector, high dependence on the trade with the European Union member states is obvious. The most important trade partners in term of export are the neighbouring countries - Slovakia (57\%), Poland and Germany. In 2016, Italian share in total wine imports reached about 28\%, then Spain 26\%, Hungary $12.5 \%$ and Slovakia 7\%. The average inter-annual growth rate $(1996$ - 2016) of wine exports value reached $17.53 \%$ in the case of all four monitored aggregations together. After the year 2013, a strong export value fall was recorded. It was caused mainly by the change in Czech vintners' strategy. They started to produce high quality grapes. There are two results of new applied strategy. The first one is related to the significant volume reduction of produced wine. The second one is related to the growth of local consumption (because of better quality and increasing local demand). Speaking about import value development - during the analysed time period - the average inter-annual growth rate of wine imports reached $10.45 \%$. As in the case of export, the import value reduction was recorded after the year 2013. The reason was monetary intervention started by the Czech National Bank in November 2013. Aggregations HS 220421 and HS 220429 are typical because of their significant negative trade balance performance. The negative trade balance is caused mainly by the import of large volumes from wine superpowers, such as Italy and Spain. Looking at unit prices in detail, we can find out that Czech vintners succeed in exporting product of higher quality for higher prices.

The trade with "Sparkling wine" showed dynamic growth in the course of the entire monitored period. France and Italy that imported sparkling wine with the total value of 14 million USD (in the year 2016) especially participated in import flows. Czech exporters succeeded mainly in two regions (Benelux and neighbouring countries surrounding the Czech Republic). In the case of trade with "Wines below 2 litres", it is important to mention the dynamic in the growth of export value, which regularly exceeded import value performance in the course of the monitored period. This tendency existed until 2013 and the Czech export was supported by the volume growth. After 2013, the above strategy was revised. In 2016, Slovakia was the most important export market, followed by the dynamically evolving Polish market. In the case of import of this aggregation, the most important positions were occupied by France and Italy. The aggregation "Wine above 2 litres" could by divided into three development stages. The share of exports was decreasing 
over the monitored period until 2006, which was caused especially by the decrease in exports to Finland and Slovakia. The sub-sequent development stage followed between the years 2007 and 2013, whereby the export volumes increased more than 5.4-times and Slovakia was absolutely dominating. The third stage features a rapid drop in produced volume, which also brought about a fall in the total export value, which was caused by the transition to the production of high quality wines, which are merchandised mainly in bottles. The producers from Italy and Spain were the major importers. The trade with "Grape must" played only a minor role in the course of the monitored period. Exporters focussed on Slovakia and Poland, grape must was imported mainly from Hungary, Italy and Spain. Grape must is a semi-product, and the producers prefer trading with finished product, which are typical because of higher added value.

As resulting from particular commodity aggregations in relation to the wine-sector, the Czech foreign trade has reached comparative advantages in the long term in the case of wine, both in containers smaller than 2 litres and those bigger than 2 litres (with an exception in 2016). Until 2002, comparative advantages were shown, in relation to the European Union, even by aggregation HS 220410. Since 2010, we can observe a decrease in the Balassa Index value in the case of wine above 2 litres, and a gradual increase in wine with a volume below 2 litres. This tendency is caused by the changes in the Czech producers' strategy. They try to switch from the production of large volumes of wine to the production of smaller volume, but with higher quality and also higher unit value.

Comparative advantages and positive balance of trade could be observed solely in the case of the aggregation "Grape must" only in the years 1996 and 2000. "Wine below 2 litres" is the main commodity aggregation over the entire monitored period. In 1996, its share in the total export was $62.83 \%$ (and $81.25 \%$ in 2016). This aggregation is exported mainly to Slovakia, Poland and Germany. During the last years, the share of export in Romania has increased. From the perspective of important Western wine producers, Czech exporters penetrated mainly Spanish and Italian markets. The abovementioned aggregation dominates also the import volumes, alongside the "Wine above 2 litres". Over the monitored years, the ratio between these items fully reversed. While in the years 1996 the import ration between "Wine above 2 litres" and "Wine below 2 litres" was nearly 2:1, during the selected years - the ratio exactly reversed. This tendency occurred as a consequence of consumers preferences. Czech consumers began to prefer highquality sorts of wines, which are associated mainly with bottled wine.

\section{Acknowledgments}

This article is prepared for the Internal Grant Agency project of FEM CULS Prague (20171024) - Analysis of the commodity structure of the Czech agrarian foreign trade.

Corresponding authors:

Ing. Jan Borák

Department of Economics, Faculty of Economics and Management

Czech University of Life Sciences Prague, Kamýcká 129, 16500 Prague - Suchdol, Czech Republic

E-mail:borak@czu.cz

\section{References}

[1] Balassa, B. (1965) "Trade liberalization and "revealed" comparative advantage", The Manchester School of Economics and Social Studies, No. 33, Vol. 2, pp. 99-123. ISSN 1049-0078. DOI 10.1111/j.1467-9957.1965.tb00050.x.

[2] Benešová, I., Novotná, Z., Šánová, P. and Laputková, A. (2016) "Economic Comparison of Agricultural Sector of Eurasian Countries - Is There Any Potential for Development Through Economic Cooperation?", AGRIS on-line Papers in Economics and Informatics, Vol. 8, No. 2, pp. 19-31. ISSN 1804-1930. DOI 10.7160/aol.2016.080202.

[3] Dal Bianco, A., Boatto, V., Caracciolo, F. and Santeramo, F. G. (2014) "Tariffs and non-tariff frictions in the world wine trade", In: MPRA Paper No. 61813, University Library of Munich, Germany. [Online]. Available: https://mpra.ub.uni-muenchen.de/61813/1/MPRA_paper_61813.pdf [Accessed: April 24, 2018]. 
[4] Dion, R. (1952) "Querelles des anciens et des modernes sur le facteurs de qualité du vin“, Annales De Géographie, Vol. 61, No. 328, pp. 417-431. [Online]. Available: http://www.jstor.org/ stable/23442544 [Accessed: April 22, 2018].

[5] Fleury, A. and Fleury, M. T. (2003) "Competitive strategies and core competencies: Perspective for the internationalization of industry in Brazil“, Integrated Manufacturing Systems, Vol. 14, No. 1, pp. 16-25. DOI 10.1108/09576060310453317.

[6] Jeníček, V. (2002) "Globalizace světového hospodářství" (In Czech), $1^{\text {st }}$ ed., Prague, C. H. Beck. Beckovy ekonomické učebnice. ISBN 80-717-9787-1.

[7] Kraus, V., Foffová, Z. and Vurm, B. (2005) "Nová encyklopedie českého a moravského vína. 1. dil"“ (In Czech), Prague: Praga Mystica. ISBN 80-867-6700-0.

[8] Kuemmerle, W. (1999) "The drivers of foreign direct investment into research and development: An empirical investigation“, Journal of International Business Studies, Vol. 30, No. 1, pp. 1-24. E-ISSN 1478-6990, ISSN 0047-2506. DOI 10.1057/palgrave.jibs.8490058.

[9] Lafay, G. (1992) "The measurement of revealed comparative advantages", In: Dagenais, M. G. and Muet, P. A. (eds.) "International Trade Modeling”, London, Chapman \& Hill, pp. 209-234. ISBN 0412450003.

[10] Lombardi, P., Dal Bianco, A., Freda, R., Caracciolo F. and Cembalo, L. (2016) "Development and trade competitiveness of the European wine sector: A gravity analyisis of intra-EU flows", Wine Economics and Policy. Vol. 5, No. 1, pp. 50-59. ISSN 2212-9774. DOI 10.1016/j.wep.2015.12.002.

[11] Peterová, J. (2013) "Ekonomika výroby a zpracování zemédělských produktů" (In Czech), $4^{\text {th }}$ ed., Prague, CULS Faculty of Economics and Management. ISBN 978-80-213-2053-6.

[12] Pyšný, T., Pošvář, Z. and Gurská, S. (2007) "Analysis of selected demand factors of wine market of the Czech Republic“, Agricultural Economics, Vol. 53, No. 7, pp. 304-311. ISSN 0139-570X. DOI 10.17221/1151-AGRICECON.

[13] Ring, P. S. and Van de Ven, A. (1994) "Developmental processes of cooperative interorganizational relationship“, Academy of Management Review, Vol. 19, No. 1, pp. 90-118. ISSN 03637425. DOI $10.2307 / 258836$.

[14] Ritchie, C. (2007) "Beyond drinking: The role of wine in the life of the UK consumer", International Journal of Consumer Studies, Vol. 31, No. 5, pp. 534-540. E-ISSN 1470-6431. DOI 10.1111/j.1470-6431.2007.00610.x.

[15] Rocchi, B. and Stefani, G. (2001) "Aspetti tecnologici, organizzativi e istituzionali nei processi di sviluppo rurale: alcune riflessioni“, In: Basile, E. and Romano, D. (Eds.) "Sviluppo rurale. Società, territorio, impresa", Milan: Franco Angeli. pp. 332-352. ISBN 88-464-7961-0.

[16] Smutka, L. and Burianová, J. (2013) "The competitiveness of Czech agrarian trade within the context of the global crisis“, Agricultural Economics, Vol. 59, No. 4, pp. 183-193. ISSN 0139-570X. DOI 10.17221/103/2012-AGRICECON.

[17] Smutka, L., Maitah, M. and Svatoš, M. (2017) "Changes in the Czech agrarian foreign trade competitiveness - different groups of partners' specifics“, Agricultural Economics, Vol. 64. ISSN 0139-570X. DOI 10.17221/399/2016-AGRICECON.

[18] Smutka, L., Svatoš, M., Tomšík, K. and Sergienko, O. I. (2016) "Foreign trade in agricultural products in the Czech Republic“, Agricultural Economics, Vol. 62, No. 1, pp 9-25. ISSN 0139-570X. DOI 10.17221/18/2015-AGRICECON.

[19] Smutka, L., Pawlak, K., Kotyza, K. and Svatoš, M. (2018) "Polish Sugar Industry Development", AGRIS on-line Papers in Economics and Informatics, Vol. 10, No. 1, pp. 71-90. ISSN 1804-1930. DOI 10.7160/aol.2018.100107.

[20] Smutka, L., Pulkrábek, J. and Benešová, I. (2014) "Current state of world sugar market", Listy Cukrovarnicke a Reparske, Vol. 130, No. 2, pp. 70-76. E- ISSN 1805-9708, ISSN 1210-3306. 
[21] Syrovátka, P., Chládkova, H. and Žufan, P. (2014) "Wine consumption in the Czech Republic and the prices of alkohol“, Agricultural Economics, Vol. 60, No. 2, pp. 89-98. DOI 10.17221/114/2013-AGRICECON.

[22] Tomšík, P. and Prokeš, A. (2011) „New strategic alliances of wine producers in the Czech Republic.“ Agricultural Economics. Vol. 54, No. 12, pp. 573-579. ISSN 0139-570X. DOI 10.17221/183/2011-AGRICECON.

[23] Tomšík, P. and Sedlo, J. (2013) "Management of wine production with regard to its implementation into the wine markets of the Czech Republic", Agricultural Economics, Vol. 59, No. 5, pp. 202-210. ISSN 0139-570X. DOI 10.17221/125/2012-AGRICECON.

[24] Widodo, T. (2009) "Comparative Advantage: Theory, Empirical Measures And Case Studies", Review of Economic and Business Studies, Vol. 2, No. 2, pp 57-82. ISSN 1843-763X.

[25] Woodward, D. and Rolfe, R. (1993) "The location of export oriented foreign direct investment in the Caribbean basin", Journal of International Business Studies, Vol. 24, No.1, pp. 121. E-ISSN 1478-6990, ISSN 0047-2506.

[26] Zaghini, A. (2003) "Trade advantages and specialization dynamics in acceding countries“, Working Paper No. 249, European Central Bank, Frankfurt am Main: 4-15, ISSN 1725-2806. 